\title{
AN EXPERIMENTAL STUDY OF THE BEHAVIOR OF A STRIP FOOTING ADJACENT TO REINFORCED SAND SLOPE ABOVE A SOFT POCKET
}

\author{
Mostafa Abd Ellatif Elsawwaf ${ }^{1}$, Waseim Rajab Azzam ${ }^{2}$ and * Engy Mohamed Kassem ${ }^{3}$ \\ Department of Structural Engineering, Tanta University, Egypt \\ *Corresponding Author, Received: 17 Oct. 2021, Revised: 01 Nov. 2021, Accepted: 23 Nov. 2021
}

\begin{abstract}
Underground soft pockets, located in a footing's failure zone, may result in foundation instability and severe super structural damage. Throughout this paper, an experimental study is presented showing the behavior of a model strip footing on both geogrid-reinforced as well as un-reinforced sand slope above a soft pocket. Affecting factors, including the depth of a soft pocket below the strip footing, the setback distance between the crest of a sand slope and the strip footing, the relative density and the various number of reinforcement layers below the footing were all examined. The stress-settlement of the model footing supported on a medium and dense sandy slope with and without a soft pocket were obtained and compared at different studied parameters. Test results indicated that the existence of such a soft pocket within the subgrade layer under the footing has a great effect on the stress and settlement of footing. Furthermore, it has been found that the inclusion of the reinforcement layers in the sand not only significantly increases the stability of the sandy slope itself, but also lessens the settlement. Moreover, two main factors upon which the efficiency of sand-geogrid systems depends are the location of the footing relative to the slope crest, and the depth of the soft pocket below the footing. Variations of the stresssettlement with different parameters are given and discussed, based on the test results.
\end{abstract}

Keywords: Sand Slope Crest, Strip Footing, Laboratory Test, Soft Pocket, Geogrid Layers.

\section{INTRODUCTION}

The construction of footings on slope surfaces, or which are adjacent to slope crests, is given keen observation in certain situations, such as footings for bridge abutments on sloping embankments. The great reduction that may occur in a footing's bearing capacity on a sloping surface depends on the location of the footing relative to the slope crest.

Several theoretical and experimental studies have been carried out, using model footings positioned on sand bed deposits and exposed to static and dynamic load. These studies have demonstrated the stress-settlement behavior of soil under loads [1].

Both slope stability and foundation bearing capacity are fundamental factors in the performance of the structure construct near a slope. One side of a foundation built on sloping land is exposed to the sloping surface. Subsequently, as the foundation soil approaches limit state, the plastic region of failure is very limited and it seriously affects the mechanical stability of the slope and thereby the bearing pressure of the foundation. Then, the bearing capacity of a foundation near a sloped fill is less than that on a level ground [2].

In engineering practice, the existence of underground soft pockets or voids under rigid surface structures (e.g., pavements, pipelines and footings) requires special attention because soft pockets can influence the integrity of structures.
If the soft pocket is located below the footing at shallower depth, the consequence can be very costly and dangerous. This may occur as a result of settlement of poorly compacted trench backfill; natural caves, tunnels, pipes, water and gas networks and old conduits. Due to population growth and increasing demand for extending urban outspread to areas that may have previously undergone mining operations, mining cavities (voids and ancient conduits) are becoming a growing concern for geotechnical engineers dealing with foundation stability issues, particularly over soft ground beds.

Many researchers have studied the performance of footing on soil with soft pocket or void under static loads [3,4]. Both Badie and Wang (1984) [5] used theoretical and experimental analysis on a model footing over clayey soil to evaluate the stability of spread footings positioned above a continuous void. The results included a fact that there is a critical region under the footing and only when the void is located within this critical region, the bearing capacity of the footing varies greatly depending on the location of the void. In 2014, Lee et al [6] used finite element analysis to study the undrained stability of strip footing on clay over single and double continuous voids. In addition to that, the yielding pressure of spread footing above single and double voids was investigated, and it was found that a failure zone is possible to occur near the nearest void [7]. 
Rodriguez-Roa (2002) [8] investigated the variance in ground surface settlement profiles caused by digging a void in layered granular soil in Santiago, Chile, and used numerical simulations to make a thorough comparison. In 2014, using PLAXIS, Mohamed [9] carried out such a numerical analysis of a strip footing which was supported on a sand bed with circular voids. The study revealed that when the depth of the void decreases and the diameter of the void increases, the bearing capacity of strip footing decreases.

Based on the papers on previous studies, it has been found that the major analysis focused on the behavior of loaded slope without considering the existence of a soft pocket within the soil. Furthermore, the main analysis in literature was concerned with the study of the existence of such a soft pocket on the behavior of footing on level ground neglecting the sand slopes. It has been observed that, the study of the behavior of loaded sand slopes with a soft pocket cannot be thoroughly investigated. Consequently, the aim of this paper is to study the ultimate bearing capacity and the mechanism of failure of a strip footing vertically loaded on geogrid reinforced and unreinforced sand slope above a soft pocket. Thus, a series of model tests on loaded strip footing near to un-reinforced and reinforced slope with existence of a soft pocket has been investigated with details.

\section{RESEARCH SIGNIFICANCE}

The significance of this study is to discuss the problem of foundations, adjacent to slopes in the existence of a soft pocket, discover and analyze such a problem to safeguard foundations from collapse. In addition, to control the settlement of footing and slope deformations, this paper studied the ultimate bearing capacity and the mechanism of failure of a strip footing vertically loaded on geogrid reinforced and un-reinforced sand slope above a soft pocket.

\section{MODEL BOX AND FOOTING}

A test box was designed to conduct the model tests, with internal dimensions of $0.90 \mathrm{~m} * 0.40 \mathrm{~m}$ in plan and $0.50 \mathrm{~m}$ in depth. As in Fig. 1, the test box was constructed of steel with a $20 \mathrm{~mm}$ thick glass front wall and was supported by two steel columns directly. These columns were firmly fixed in two horizontal beams made of steel. The glass side made it possible to see during preparation, and the deformation of sand particles could also be seen during the process of testing. The tank box was designed to be stiff enough to minimize out-of-plane displacement while maintaining plane strain conditions.
Interior walls of the tank are furbished smoothly to minimize the friction with the sand as much as possible by attaching fiber glass onto the inside walls.

The model strip footing was constructed of steel and included a hole in the top centre to accommodate the bearing ball. Footing dimensions are $398 \mathrm{~mm}$ in length, $100 \mathrm{~mm}$ in width (B) and $20 \mathrm{~mm}$ in thickness. With the aim of maintaining plane strain conditions throughout the confines of the test set-up, the strip footing was placed on the sand bed, with its length running the width of the test tank. The two ends of the footing plate were furbished smoothly, to reduce the end friction effects. Through a bearing ball, the load is transferred to the strip footing. Such a configuration created a hinge, which allowed the footing to rotate freely as it approached failure and eliminated any potential moment transfer from the loading fixture.

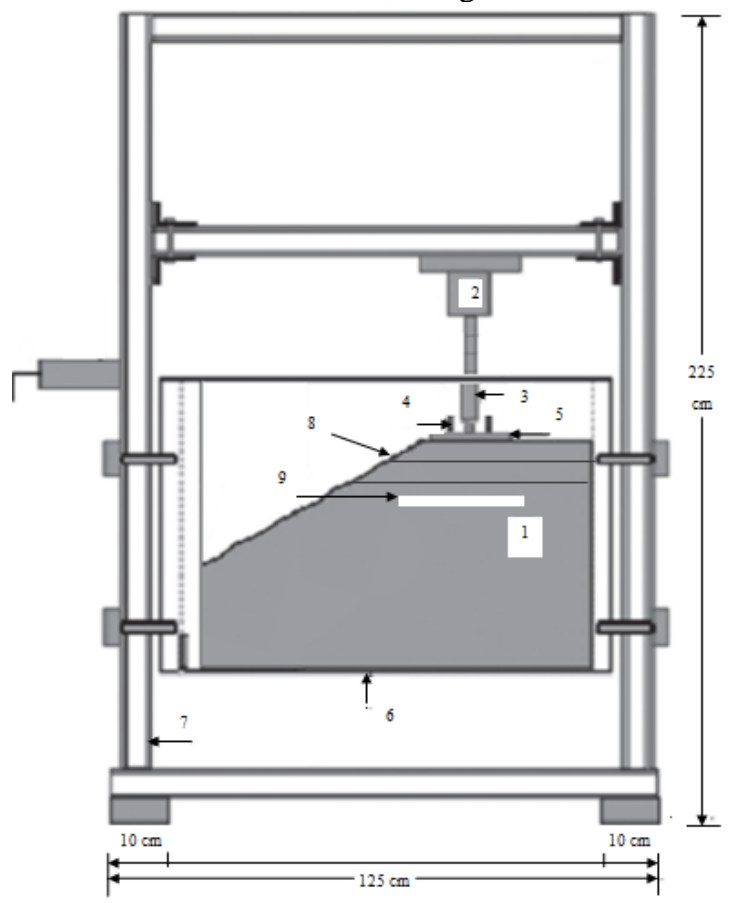

1. The sand soil,

2. Hydraulic jack,

3. Load cell,

4. LVDTs,

5. Strip footing,

6. Test tank,

7. The test frame,

8. Geogrid layer,

9. Styrofoam layer

Fig.1: Schematic diagram of the test tank (without scale).

\section{MATERIAL AND METHODS}

\subsection{Test Material}

This study utilized medium to coarse sand that has been cleaned, dried, and sorted by particle size. Its composition ranged from rounded to sub-rounded particles. The sand has an extremely 
low impurity level with a quartz (SiO2) content of 97 percent. The estimation of the specific gravity of the soil particles was based on using the gas jar technique. Three tests were carried out producing an average value of 2.63. The sand soil's maximum and minimum dry unit weights were found to be 18.9 and $14.4 \mathrm{kN} / \mathrm{m}^{3}$, respectively and the corresponding values of the minimum and the maximum void ratios are 0.39 and 0.51 , respectively.

Dry sieving was applied to determine the distribution of the particle size. The effective size $\left(\mathrm{D}_{10}\right),\left(\mathrm{D}_{60}\right)$, the uniformity coefficient $\left(\mathrm{C}_{\mathrm{u}}\right)$, and the coefficient of curvature $\left(\mathrm{C}_{\mathrm{c}}\right)$ for the sand were $0.20 \mathrm{~mm}, 0.52 \mathrm{~mm}, 2.6$ and 1.05 , respectively.

Sand beds were placed in $50 \mathrm{~mm}$ thick layers by using the predetermined weight method $[10,11]$. The relative density achieved throughout the tests was monitored by collecting samples in small cans of known volume placed at various positions in the tank $[12,13,14]$. This study provided a uniform relative density of approximately ( $D_{\mathrm{r}}$ ) $55 \%$ and $80 \%$ with a unit weight of 16.6 and $17.7 \mathrm{kN} / \mathrm{m}^{3}$, respectively. The estimated internal friction angles of the sand determined from direct shear tests using specimens prepared by dry tamping at the same relative densities were $37^{\circ}$ and $41.7^{\circ}$, respectively.

\subsection{Model of a Soft Pocket}

Since Styrofoam is made up of $98 \%$ air, which makes it light and buoyant, a Styrofoam layer was used as a soft pocket in this study. Styrofoam was placed beneath the centre of the footing and parallel with the width of the tank [15]. The dimensions of Styrofoam was $400 \mathrm{~mm}$ in length, $200 \mathrm{~mm}$ in width (w) and $20 \mathrm{~mm}$ in thickness in all the tests. As seen in Fig. 2, Styrofoam is a type of polystyrene foam that is typically white in colour. The properties, as in Table 1 , were obtained from the manufacturer.

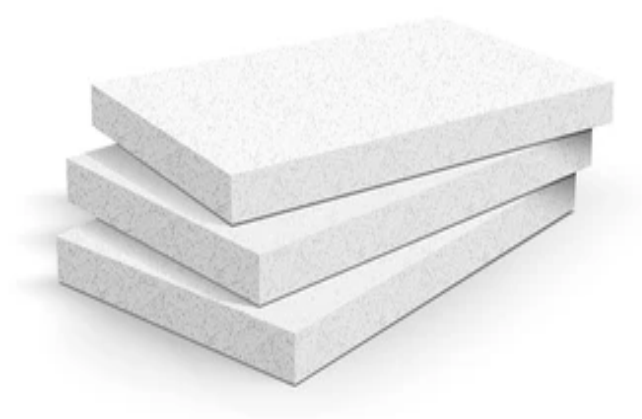

Fig. 2: The model of a soft pocket (Styrofoam layer).

Table 1: Properties of Styrofoam.

\begin{tabular}{ll}
\hline Property & Value \\
\hline $\begin{array}{l}\text { Thermal Resistance per inch (25 } \\
\text { mm) }\end{array}$ & $5.0(.88)$ \\
Compressive Strength, ASTM & $30(207)$ \\
$\begin{array}{l}\text { D1621, psi (kPa), min. } \\
\text { Surface Burning Characteristics, }\end{array}$ & \\
$\begin{array}{l}\text { ASTM E84 for both foam core } \\
\text { and finished product }\end{array}$ & Class A \\
$\begin{array}{l}\text { Flame Spread } \\
\text { Smoke Developed } \\
\text { Elasticity Modulus (E) kN/m² } \\
\left.\text { Density (kN/m }{ }^{3}\right)\end{array}$ & 25 \\
\hline
\end{tabular}

\subsection{Geogrid Reinforcement}

One type of geogrid was used as reinforcing material for the model tests as in Fig. 3. However, Table 2 provides the physical and technical properties of the grids as obtained from a manufacturer's data sheet.

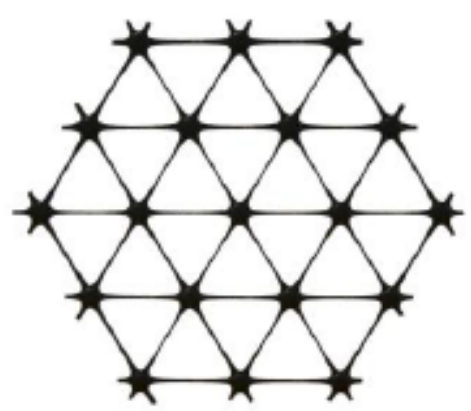

Fig. 3: Geogrid layer.

Table 2: The Geogrid's properties.

\begin{tabular}{ll}
\hline Description & Value \\
\hline Type of polymer & $\begin{array}{l}100 \% \\
\text { polypropylene }\end{array}$ \\
$\begin{array}{l}\text { Radial Secant Stiffness at } \\
275\end{array}$ & \\
$\begin{array}{l}\text { R.5\% strain }(\mathrm{kN} / \mathrm{m}) \\
\text { Radial Secant Stiffness at } \\
\text { 2.0\%strain (kN/m) }\end{array}$ & 205 \\
$\begin{array}{l}\text { Radial Secant Stiffness } \\
\text { Ratio }\end{array}$ & 0.75 \\
$\begin{array}{l}\text { Junction Efficiency \% } \\
\text { Hexagon Pitch (mm.) }\end{array}$ & 100 \\
Weight $\left(\mathrm{kg} / \mathrm{m}^{2}\right)$ & 66 \\
\hline
\end{tabular}

\subsection{The Loading System}

A hand-operated hydraulic jack was used in the loading system and pre-calibrated load cell mounted by a horizontal steel beam based on the two steel columns. The load was applied using the hydraulic jack in modest increments and maintained until the vertical displacements of the footings had stabilized. 


\subsection{The Test Programme and Experimental Setup}

The experimental work aimed to study the effects of stabilizing a dense and medium reinforced sand slope on the load-settlement behavior of a strip footing placed at various locations, adjacent to the slope crest, and above a soft pocket. Soil was set up to form a slope of 2(V):3(H). Positioning sand beds for sand modeling cases was done via the two chosen relative densities medium state $\left(\mathrm{D}_{\mathrm{r}}=55 \%\right)$ and dense state $\left(D_{r}=80 \%\right)$. The inside surfaces of the test box were marked at $50 \mathrm{~mm}$ intervals to facilitate the preparation of the sand beds in layers.

In the reinforcement model level, a geogrid layer was positioned followed by a sand layer, and so on. Then, the preparation of sand beds over the geogrid layer went on up to the required level in layers for a specific depth of embedment. Particular care was given to level the slope face by special rulers so that the relative density of the top surface would not be affected.

The predetermined weight of sand for each layer of $50 \mathrm{~mm}$ thick was placed and the targeted depth, which was previously identified by lines drawn on the internal sides of the test tank, along with density, was reached through using a compacted solid plate hammer. To complete the sand preparation in the test tank, equal predetermined weights of ten layers were utilized; then, the top layer is leveled using a ruler with sharp edges [16,17].

The relative density carried out during the tests was measured by collecting samples in small cans of known volume placed at various positions in the tank. The sand relative densities obtained using the cans were found to be within the range of $D_{r}=55 \% \pm 1.31 \%$ in the medium dense sand state and $\mathrm{D}_{\mathrm{r}}=80 \% \pm 1.25 \%$ in the dense sand state. After that, the model strip footing was placed on the compacted sand surface, and the load was applied until reaching failure. New sheets of geogrid were used to conduct all tests. Settlements of model footing were measured with the help of two $100 \mathrm{~mm}$ capacity LVDTs, with a sensitivity of $1 / 100 \mathrm{~mm}$ placed on opposite sides of the footing (Fig. 4).

In total, 104 tests were conducted within the lab. The response of the model footing supported on un-reinforced and reinforced level ground was initially determined (18 tests with soft pockets in different depths below the footing and 8 tests without soft pockets) for two chosen relative densities medium state $\left(D_{r}=55 \%\right)$ and dense state
$\left(D_{r}=80 \%\right)$. Following that, were the procedures of 11 series of tests (78 tests) in order to study the effect of various parameters on the behavior of footing when placed on un-reinforced and reinforced sand slope above a soft pocket.

The parameters were varied, including the setback distance between the slope crest and the strip footing (b), the depth of a soft pocket below the footing $(\mathrm{Y})$, the relative density $\left(\mathrm{D}_{\mathrm{r}}\right)$ and the different numbers of geogrid layers beneath the footing $(\mathrm{N})$ as illustrated in (Fig.5) whereas Table 3 summarises all test programmes, showing both constant and variable parameters.
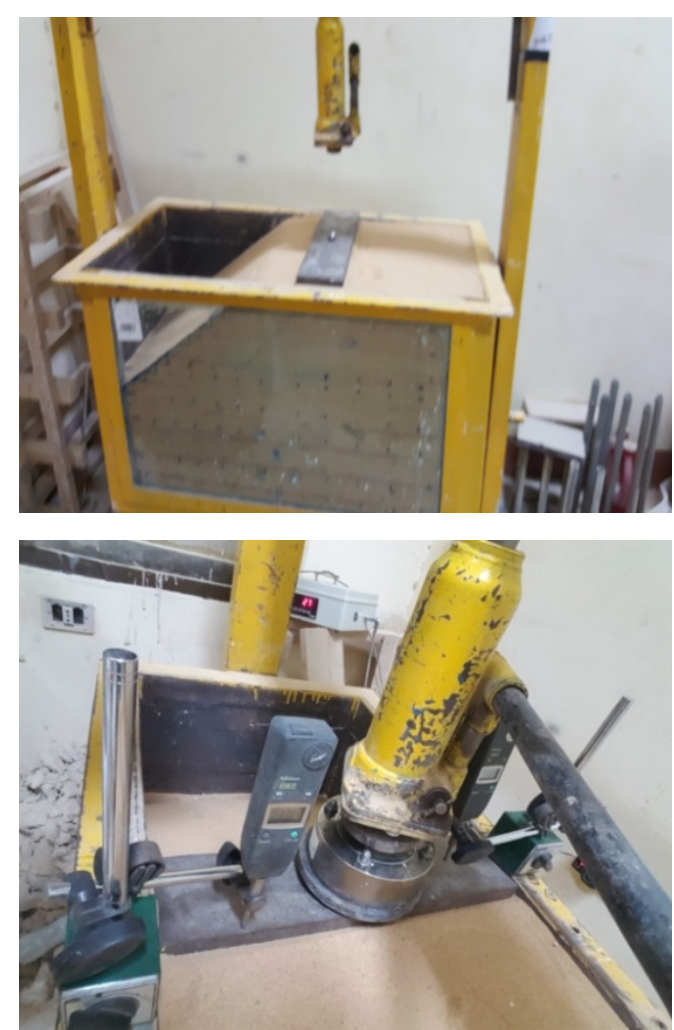

Fig. 4: Arrangement for application of load and Measurement of settlement.

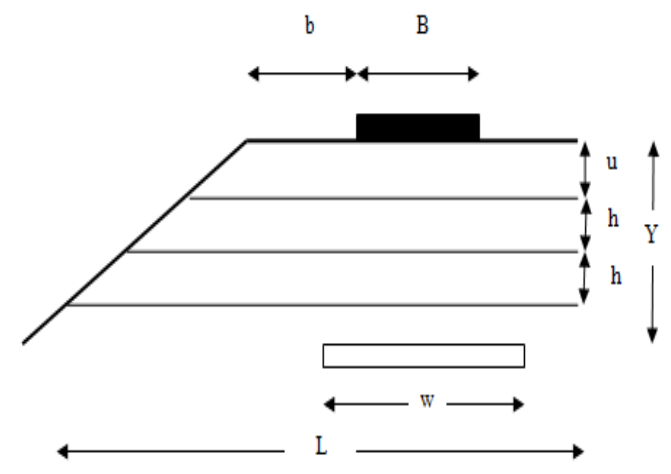

Fig. 5: The setup for present study. 
Table 3: Model test program for level ground and sand slope with and without a soft pocket for different sand relative density:

\begin{tabular}{|c|c|c|c|c|}
\hline Series & Constant parameters & \multicolumn{3}{|c|}{ Variable parameters } \\
\hline \multirow[b]{2}{*}{1} & \multirow[b]{2}{*}{ Un-reinforced level ground } & \multicolumn{2}{|l|}{$\mathrm{D}_{\mathrm{r}}=55 \%$} & $\mathrm{D}_{\mathrm{r}}=80 \%$ \\
\hline & & \multicolumn{2}{|c|}{$\begin{array}{l}\text { No soft pocket, } \\
\mathrm{Y} / \mathrm{B}=1.0,1.5,2.0\end{array}$} & $\begin{array}{l}\text { No soft pocket, } \\
\mathrm{Y} / \mathrm{B}=1.0,1.5,2.0\end{array}$ \\
\hline \multirow[b]{2}{*}{2} & \multirow[b]{2}{*}{ Un-reinforced sand slope, $\mathrm{b} / \mathrm{B}=0$} & \multicolumn{2}{|c|}{$\mathrm{D}_{\mathrm{r}}=55 \%$} & $\mathrm{D}_{\mathrm{r}}=80 \%$ \\
\hline & & \multicolumn{2}{|c|}{$\begin{array}{l}\text { No soft pocket, } \\
\mathrm{Y} / \mathrm{B}=1.0,1.5,2.0\end{array}$} & $\begin{array}{l}\text { No soft pocket, } \\
\mathrm{Y} / \mathrm{B}=1.0,1.5,2.0\end{array}$ \\
\hline \multirow[b]{2}{*}{3} & \multirow[b]{2}{*}{ Un-reinforced sand slope, b/B=1.0 } & \multicolumn{2}{|c|}{$\mathrm{D}_{\mathrm{r}}=55 \%$} & $\mathrm{D}_{\mathrm{r}}=80 \%$ \\
\hline & & \multicolumn{2}{|c|}{$\begin{array}{l}\text { No soft pocket, } \\
\mathrm{Y} / \mathrm{B}=1.0,1.5,2.0\end{array}$} & $\begin{array}{l}\text { No soft pocket, } \\
\mathrm{Y} / \mathrm{B}=1.0,1.5,2.0\end{array}$ \\
\hline \multirow[b]{2}{*}{4} & \multirow[b]{2}{*}{ Un-reinforced sand slope, $\mathrm{b} / \mathrm{B}=2.0$} & \multicolumn{2}{|c|}{$\mathrm{D}_{\mathrm{r}}=55 \%$} & $\mathrm{D}_{\mathrm{r}}=80 \%$ \\
\hline & & \multicolumn{2}{|c|}{$\begin{array}{l}\text { No soft pocket, } \\
\mathrm{Y} / \mathrm{B}=1.0,1.5,2.0\end{array}$} & $\begin{array}{l}\text { No soft pocket, } \\
\mathrm{Y} / \mathrm{B}=1.0,1.5,2.0\end{array}$ \\
\hline \multirow{2}{*}{5} & \multirow{2}{*}{ Reinforced level ground, No soft pocket } & \multicolumn{2}{|c|}{$\mathrm{D}_{\mathrm{r}}=55 \%$} & $\mathrm{D}_{\mathrm{r}}=80 \%$ \\
\hline & & \multicolumn{2}{|l|}{$\mathrm{N}=1,2,3$} & $\mathrm{~N}=1,2,3$ \\
\hline 6 & Reinforced level ground, $\mathrm{Y} / \mathrm{B}=1.0, \mathrm{~N}=1$ & \multicolumn{3}{|c|}{$\mathrm{D}_{\mathrm{r}}=55 \%$ and $\mathrm{D}_{\mathrm{r}}=80 \%$} \\
\hline & & $\mathrm{D}_{\mathrm{r}}=55 \%$ & & \\
\hline 7 & Reinforced level ground, Y/B=1.5 & $\mathrm{N}=1,2$ & & \\
\hline $\mathbf{8}$ & Reinforced loyel oround Y/B-? 0 & $\mathrm{D}_{\mathrm{r}}=55 \%$ & & \\
\hline 8 & Reinrorced level ground, Y/B=2.0 & $\mathrm{N}=1,2,3$ & & \\
\hline $\mathbf{9}$ & Reinforced sand slope, No soft pocket, & $\mathrm{b} / \mathrm{B}=0.0$ & $\mathrm{~b} / \mathrm{B}=1.0$ & $\mathrm{~b} / \mathrm{B}=2.0$ \\
\hline J & $\mathrm{D}_{\mathrm{r}}=55 \%$ & $\mathrm{~N}=1,2,3$ & $\mathrm{~N}=1,2,3$ & $\mathrm{~N}=1,2,3$ \\
\hline 10 & $\begin{array}{l}\text { Reinforced sand slope, } Y / B=1.0, N=1 \text {, } \\
D_{r}=55 \%\end{array}$ & $\mathrm{~b} / \mathrm{B}=0.0$ & & \\
\hline 11 & Reinforced sand slone $\mathrm{Y} / \mathrm{B}=15 \mathrm{D}=55 \%$ & $\mathrm{~b} / \mathrm{B}=0.0$ & $\mathrm{~b} / \mathrm{B}=1.0$ & $\mathrm{~b} / \mathrm{B}=2.0$ \\
\hline $\mathbf{I 1}$ & Keiniorced sand siope, $\mathbf{y} / \mathrm{B}=1.5, D_{\mathrm{r}}=55 \%$ & $\mathrm{~N}=1,2$ & $\mathrm{~N}=1,2$ & $\mathrm{~N}=1,2$ \\
\hline 12 & & $\mathrm{~b} / \mathrm{B}=0.0$ & $\mathrm{~b} / \mathrm{B}=1.0$ & $\mathrm{~b} / \mathrm{B}=2.0$ \\
\hline 12 & Reinforced sand siope, Y/B=L.0, $D_{\mathrm{r}}=\zeta$ \% & $\mathrm{N}=1,2,3$ & $\mathrm{~N}=1,2,3$ & $\mathrm{~N}=1,2,3$ \\
\hline 13 & Reinforced sand slope, No soft pocket, & $\mathrm{b} / \mathrm{B}=0.0$ & $\mathrm{~b} / \mathrm{B}=1.0$ & $\mathrm{~b} / \mathrm{B}=2.0$ \\
\hline 13 & $\mathrm{D}_{\mathrm{r}}=80 \%$ & $\mathrm{~N}=1,2,3$ & $\mathrm{~N}=1,2,3$ & $\mathrm{~N}=1,2,3$ \\
\hline 14 & $\begin{array}{l}\text { Reinforced sand slope, } Y / B=1.0, N=1 \text {, } \\
D_{r}=80 \%\end{array}$ & $\mathrm{~b} / \mathrm{B}=0.0$ & & \\
\hline & Roinforced cand slone $\mathrm{Y} / \mathrm{R}=15 \mathrm{D}=80 \%$ & $\mathrm{~b} / \mathrm{B}=0.0$ & $\mathrm{~b} / \mathrm{B}=1.0$ & $\mathrm{~b} / \mathrm{B}=2.0$ \\
\hline 15 & Reinforced sand siope, y/B=1.5, $D_{\mathrm{r}}=80 \%$ & $\mathrm{~N}=1,2$ & $\mathrm{~N}=1,2$ & $\mathrm{~N}=1,2$ \\
\hline & & $\mathrm{b} / \mathrm{B}=0.0$ & $\mathrm{~b} / \mathrm{B}=1.0$ & $\mathrm{~b} / \mathrm{B}=2.0$ \\
\hline 16 & sand slope, Y/B=2.0, $D_{\mathrm{r}}=80 \%$ & $\mathrm{~N}=1,2,3$ & $\mathrm{~N}=1,2,3$ & $\mathrm{~N}=1,2,3$ \\
\hline
\end{tabular}

Note: See Fig. 5 for definition of the variable. $(B)=100 \mathrm{~mm},(w)=2 B$ were always constant. In reinforced tests, $(\mathrm{u} / \mathrm{B})=0.50,(\mathrm{~h} / \mathrm{B})=0.5$ were always constant $[1,14],(\mathrm{N})$ is the number of the geogrid layers $=1,2$ and 3.

\section{SCALE EFFECTS AND LIMITATIONS}

The physical model used in the present study is a small scale while the problem encountered in the field is a prototype footing-cell system. Despite the fact that the use of small scale models to investigate the behavior of a full-scale foundation is an excessively used technique, it is well-known that due to scale effects and the nature of soil, particularly granular soils, soils may not play the same role in the laboratory models as in the model [18]. Also, it should be noted that the experimental results are obtained for only one size of footing width, and one type of sand and one angle of slope inclination. Therefore, specific applications should only be made after considering the above limitations. In

spite of the mentioned disadvantages, that scaling effects will occur in model tests and the test results are of limited use in predicting the behavior of a particular prototype, the study has shed in sighted light on the fundamental mechanism that illustrates the way footings behave on being exposed to vertical loads, indicating the advantages that could be realized through using geogrid layers to reinforced sandy 
soils which provided a useful basis for further research using full-scale tests or centrifugal model tests as well as numerical studies leading to an increased understanding of the real behavior and accurate design in application of soil reinforcement $[1,14,17]$.

\section{THE EXPERIMENTAL RESULTS AND DISCUSSION}

A number of tests were carried out on a model of a strip footing on un-reinforced and reinforced sand slope with a soft pocket. The effect of the setback distance between the footing and the slope crest, the depths of the soft pocket below the footing, the relative density of sand and the number of reinforcement layers beneath the footing on the ultimate bearing capacity were obtained and discussed.

The ultimate bearing capacity (ultimate B. C.) for the footing-soil systems are determined from the stress - settlement curves as the pronounced peaks, after which the footing collapses and the load decreases. In this study, there is no peak failure exhibited so, the ultimate B. C. was determined by choosing the tangent intersection method [2,9,19].

Figure 6 shows the variations of stress with settlement ratios (S/B) for footing on sand without soft pocket for level ground and sand slope at $\mathrm{b} / \mathrm{B}=0.0,1.0$ and 2.0 for different sand relative density.

The findings show that, the ultimate B. C. increases with increasing the setback distance between the footing and the slope crest. When the footing is moved away from the slope crest $(\mathrm{b} / \mathrm{B}=0)$ to the setback distance at $\mathrm{b} / \mathrm{B}=2.0$, there is a serious increase in ultimate $\mathrm{B}$. C. an average value of $100 \%$ and $100 \%$ for different sand relative density. Also, the $(\mathrm{S} / \mathrm{B})$ were noticeably increased by $175 \%$ and $67 \%$ at ultimate B. C. for different sand relative density.

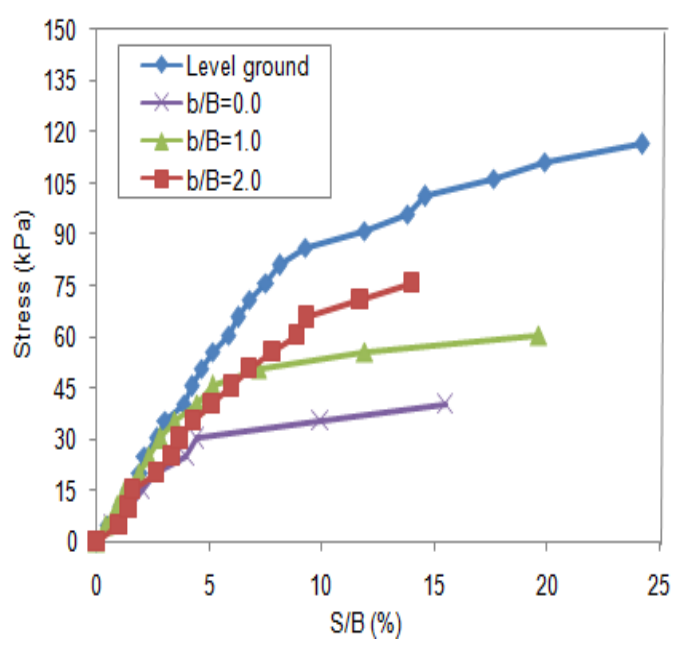

(a) $\mathrm{D}_{\mathrm{r}}=55 \%$.
The variations of stress with (S/B) for footing on sand with a soft pocket at $\mathrm{Y} / \mathrm{B}=$ 1.5 for unreinforced sand slope for different

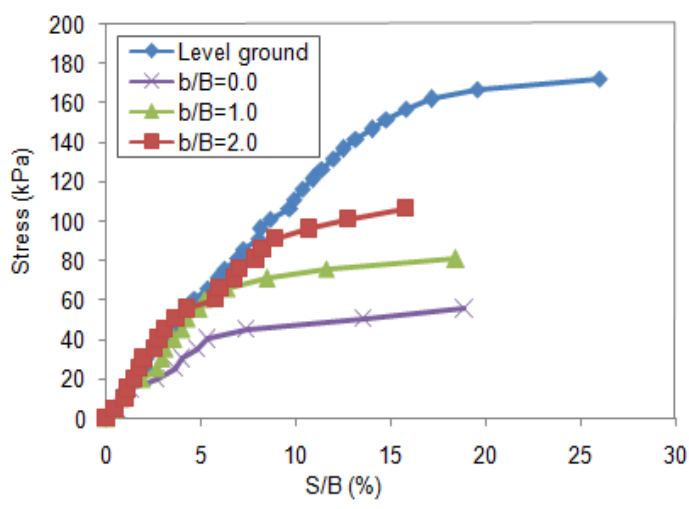

(b) $\mathrm{D}_{\mathrm{r}}=80 \%$

Fig. 6: Variations of stress with (S/B) for footing on sand without a soft pocket for level ground and sand slope a different setback distance (b/B) for different sand relative density.

sand relative density are shown in Fig. 7. It can be noted that the ultimate $\mathrm{B}$. C. decreased about $64 \%$ and $56 \%$ at $\mathrm{b} / \mathrm{B}=0.0$ compared to $\mathrm{b} / \mathrm{B}=2.0$ for different sand relative density. However, the settlement ratios $(\mathrm{S} / \mathrm{B})$ at the ultimate $\mathrm{B}$. C. increased about $100 \%$ and $67 \%$ at $\mathrm{b} / \mathrm{B}=2.0$ compared to $\mathrm{b} / \mathrm{B}=0.0$ for different sand relative density.

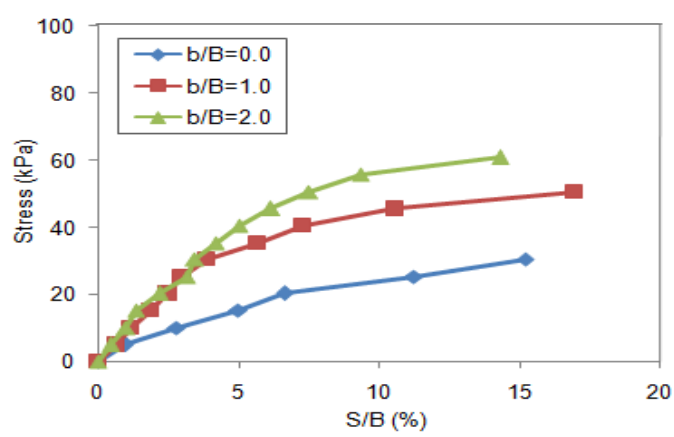

(a) $\mathrm{D}_{\mathrm{r}}=55 \%$.

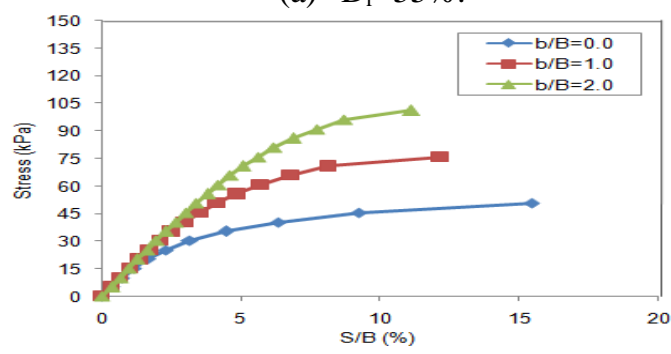

(b) $\mathrm{D}_{\mathrm{r}}=80 \%$.

Fig. 7: Variations of stress with (S/B) for footing on sand with a soft pocket at $\mathrm{Y} / \mathrm{B}=1.5$ for unreinforced sand slope for different sand relative density. 
Figure 8 shows the variations of stress with (S/B) for footing on sand with a soft pocket at $\mathrm{Y} / \mathrm{B}=1.5$ for reinforced sand slope for different sand relative density at $\mathrm{N}=2$. It has been observed that the ultimate B. C. increased by $133 \%$ and $100 \%$ at $b / B=2.0$ for reinforced sand slope compared to $\mathrm{b} / \mathrm{B}=0.0$ for different sand relative density at $\mathrm{N}=2$. Also, $(\mathrm{S} / \mathrm{B})$ at the ultimate $\mathrm{B}$. C. increased by $44 \%$ and $25 \%$ for different sand relative density.

It can be concluded that the inclusion of soil reinforcement is acting more efficiently to reduce the footing settlement and hence improve the overall behavior of loaded footing on sand slopes above a soft pocket.

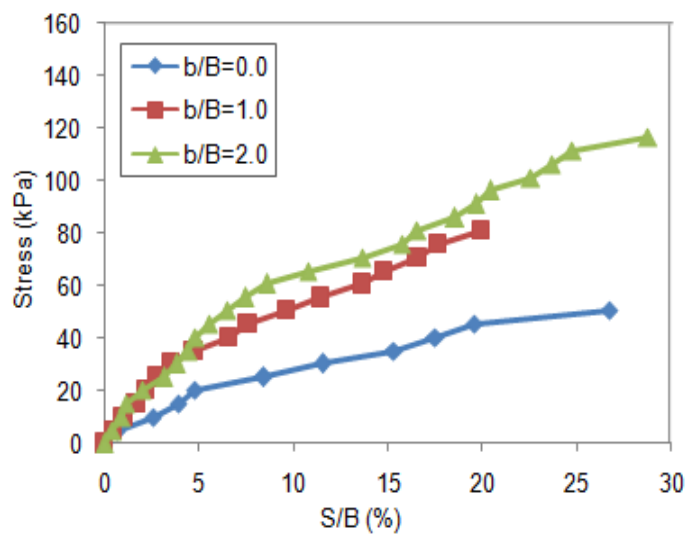

(a) $\mathrm{D}_{\mathrm{r}}=55 \%$

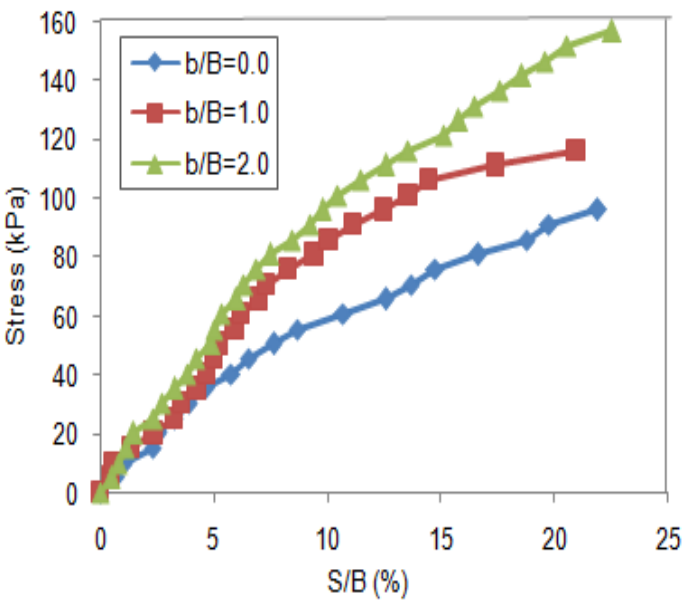

(b) $\mathrm{D}_{\mathrm{r}}=80 \%$.

Fig. 8: Variations of stress with (S/B) for footing on sand with a soft pocket at $\mathrm{Y} / \mathrm{B}=1.5$ for reinforced sand slope for different sand relative density at $\mathrm{N}=2$.

\subsection{The Effect of the Number of the Geogrid Layers}

The effect of the geogrid layers on sand slope with a soft pocket on the B. C. is estimated by Bearing Capacity Ratio (BCR) as:
$\boldsymbol{B C R}=$ Ultimate B. C. reinforced sand slope / Ultimate B. C. un-reinforced sand slope

Figure 9 shows the variation of BCR against the number of layers $(\mathrm{N})$ at $\mathrm{Y} / \mathrm{B}=2.0$ and $\mathrm{b} / \mathrm{B}=1.0$. It can be seen that the inclusion of soil reinforcement causes additional considerable improvements in the BCR of the footing which increases with the number of geogrid layers. When $\mathrm{N}=1$ the BCR is 1.375 and when using $\mathrm{N}=3$, it becomes 2.25 at $\mathrm{D}_{\mathrm{r}}=55 \%$. However, this increase decreased to 1.25 and 1.833 at $\mathrm{N}=1$ and 3 , respectively at $\mathrm{D}_{\mathrm{r}}=80 \%$.

This means that the BCR value increases slightly with decreasing sand relative density at any number of geogrid layers.

This can be attributed to the fact that in dense sand, the sand layer between the footing base and the soft pocket is more rigid than that for medium dense sand, which leads to the effect of surface footing load transferred to the soft pocket faster than that in medium sand [9].

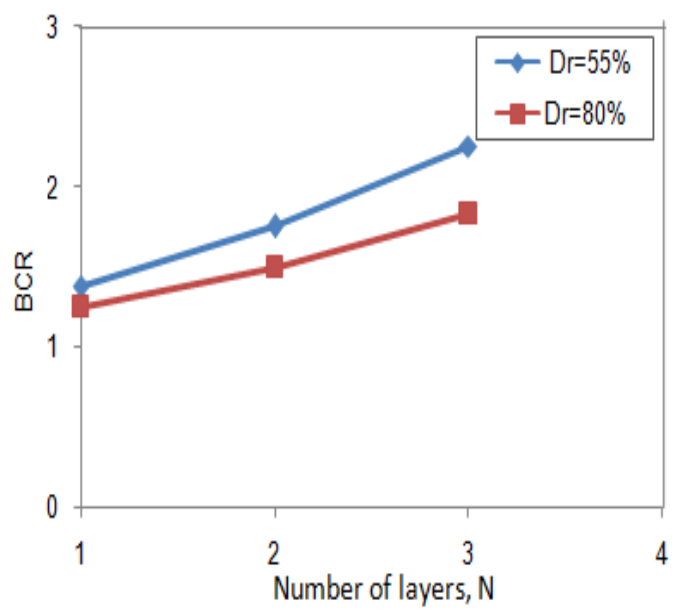

Fig. 9: Variations of BCR with number of geogrid layers $(N)$ at $\mathrm{Y} / \mathrm{B}=2.0$ and $\mathrm{b} / \mathrm{B}=1.0$ for different sand relative density.

\subsection{The Effect of the Depth of the Soft Pocket Below the Footing}

Figures 10 (a,b,c) demonstrate the variations of $\mathrm{BCR}$ with $\mathrm{Y} / \mathrm{B}$ at $\mathrm{N}=1$ for different sand relative density at $\mathrm{b} / \mathrm{B}=0.0,1.0$ and 2.0.

The ultimate $\mathrm{B}$. C. of footing proportionally increases with the depth of a soft pocket below the footing where the stress-settlement ratios curve of footing approaches to the corresponding ratios curve in the condition of having no soft pocket. Based on that, it can be seen that the efficacy of geogrid layer is found to be maximum when the depth of a soft pocket below the footing $\mathrm{Y} / \mathrm{B}=1.0$ where the $\mathrm{BCR}$ values decreases with an increase in the depth of the soft pocket $(\mathrm{Y} / \mathrm{B}=2.0)[9,20]$. 


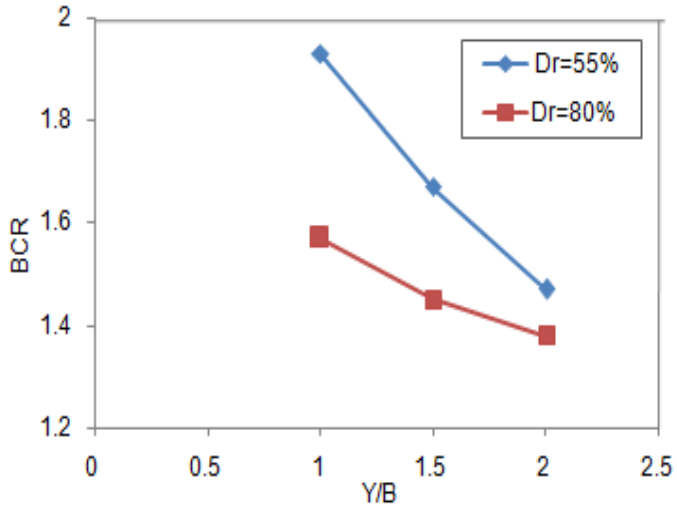

(a) Variations of BCR for $b / B=0.0$.

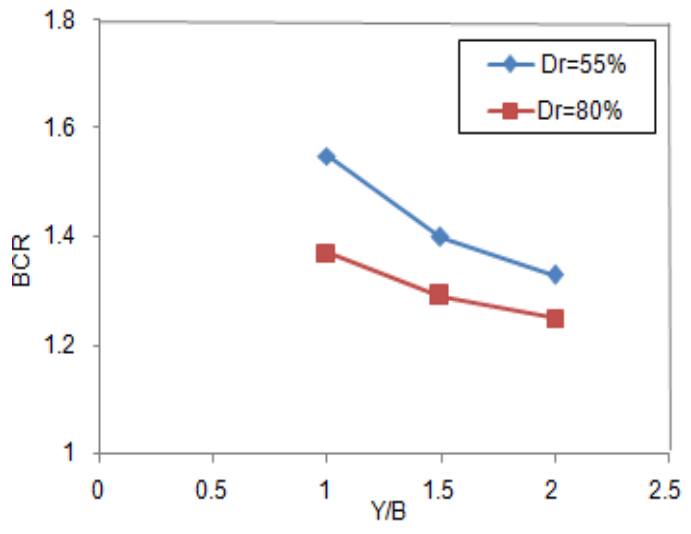

(b)Variations of BCR for $\mathrm{b} / \mathrm{B}=1.0$.

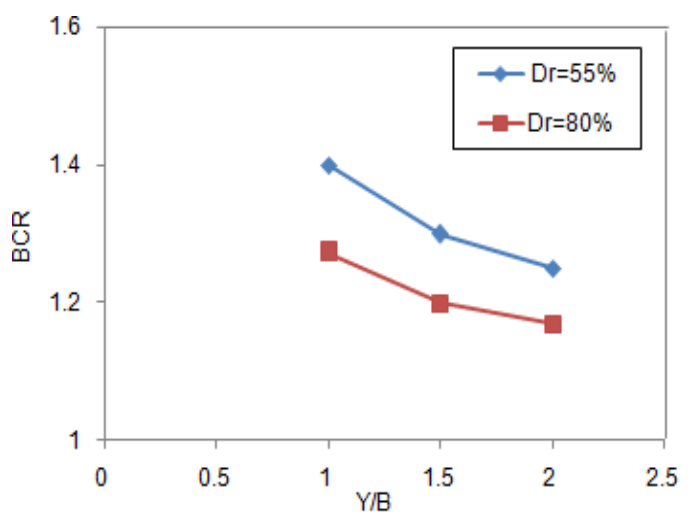

(c) Variations of BCR for $\mathrm{b} / \mathrm{B}=2.0$.

Fig. 10: Variations of BCR with $\mathrm{Y} / \mathrm{B}$ at $\mathrm{N}=1$ for different sand relative density.

\subsection{The Effect of the Footing Location Relative to the Slope Crest}

Figure 11 shows the variations of BCR with $\mathrm{b} / \mathrm{B}$ at $\mathrm{Y} / \mathrm{B}=1.5$ and $\mathrm{N}=2$ for different sand relative density.

When the footing is positioned on the edge of the slope $b / B=0.0$, the efficacy of the geogrid layer is found to be at its greatest. BCR decreases when the footing setback distance between the slope crest and the footing increases. Whereas, at $\mathrm{b} / \mathrm{B}=2.0$ and $\mathrm{N}=2$, the efficiency of the geogrid layer is observed to be reduced beyond a footing [21].

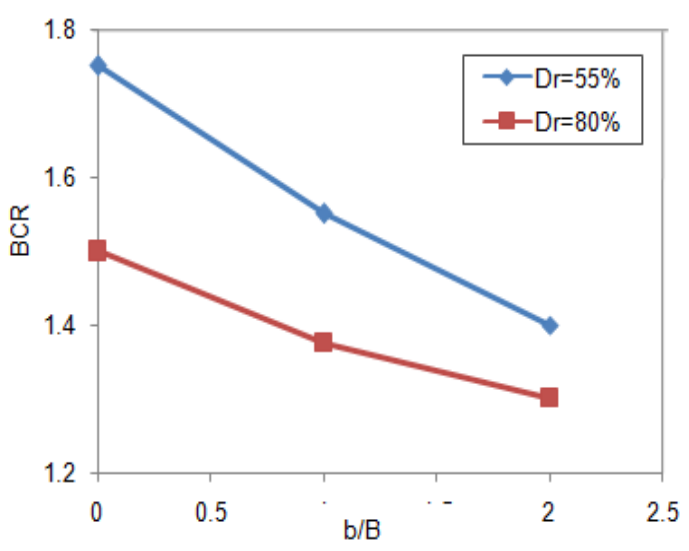

Fig. 11: Variations of $\mathrm{BCR}$ with $\mathrm{b} / \mathrm{B}$ at $\mathrm{Y} / \mathrm{B}=1.5$ and $\mathrm{N}=2$ for different sand relative density.

\section{CONCLUSIONS}

This experimental study aims to investigate the behavior of a strip footing near to reinforced sand slope above a soft pocket, taking into consideration multiple variables and factors including the depth of the soft pocket, the setback distance between the crest of the slope and the strip footing, the number of reinforcement layers and the relative densities. The conducted tests resulted in the following :

1. The results clearly show that the existence of a soft pocket below the foundation has a great effect on the ultimate bearing capacity and settlement. The ultimate bearing capacity of footing on sand slope $2(\mathrm{~V}): 3(\mathrm{H})$ above a soft pocket in case of $\mathrm{b} / \mathrm{B}=1.0$ and $\mathrm{Y} / \mathrm{B}=1.5$ is reduced by $37 \%$ compared to the same case without a soft pocket at $\mathrm{D}_{\mathrm{r}}=55 \%$.

2. Based on the experimental results, the use of soil reinforcement improves the overall behavior of loaded footing on sand slopes above soft pockets by reducing footing settlement and thus improving overall behavior. The ultimate B. C. and the settlement at the ultimate $B$. C. of a footing near to reinforced sand slope above a soft pocket increased about $96 \%$ and 65\%, respectively in case of $\mathrm{b} / \mathrm{B}=1.0, \mathrm{Y} / \mathrm{B}=1.5$ and $\mathrm{N}=2.0$ compared to the same case without geogrid layers at $\mathrm{D}_{\mathrm{r}}=55 \%$.

3. The inclusion of soil reinforcement causes additional, considerable improvements in the bearing capacity ratio (BCR) of the footing which increases with the number of geogrid layers. When $\mathrm{N}=1$ the BCR is 1.375 and when using $\mathrm{N}=3$, it becomes 2.25 at $\mathrm{D}_{\mathrm{r}}=55 \%$. However, this increase decreased to 1.25 and 1.833 at $\mathrm{N}=1$ and 3, respectively at $\mathrm{D}_{\mathrm{r}}=80 \%$ in case of $\mathrm{Y} / \mathrm{B}=2.0$ and $\mathrm{b} / \mathrm{B}=1.0$.

4. The results of the study also show that the effect of a soft pocket on the BCR of sand is inversely proportional with relative density of 
sand where the BCR increased by $22 \%$ and $12 \%$ at $\mathrm{D}_{\mathrm{r}}=55$ and $80 \%$, respectively when $\mathrm{Y} / \mathrm{B}$ decreased from 2.0 to 1.0 at $\mathrm{b} / \mathrm{B}=1.0$ and $\mathrm{N}=1.0$. 5. The results indicate that the effect of the slope on the footing behavior approximate decreased at the setback distance equal twice footing width especially at the dense sand state $\left(D_{\mathrm{r}}=80 \%\right)$. The BCR values decreased by $35 \%$ and $20 \%$ when $\mathrm{b} / \mathrm{B}$ increased from 0.0 to 2.0 at $\mathrm{Y} / \mathrm{B}=1.5$ and $\mathrm{N}=2.0$ for $\mathrm{D}_{\mathrm{r}}=55$ and $80 \%$, respectively.

\section{ACKNOWLEDGMENTS}

The tests were performed in the Soil Mechanics Laboratory of the Structural Engineering Department, University of Tanta, which is acknowledged.

\section{REFERENCES}

[1] Mostafa A. El S. and Ashraf K. N., Cyclic settlement behavior of strip footings restingon reinforced layered sand slope. Journal of Advanced Research, 2012. 315-324.https//doi:10.1016/j.jare.2011.10.00 2.

[2] M. Salih K. and Mustafa L., Model Studies of Bearing Capacity of Strip Footing on Sand Slope. KSCE Journal of Civil Engineering, $2012 . \quad$ 17(4):699-711.https://doi 10.1007/s12205-013-0406-X.

[3] Baus, R. L. and Wang, M. C., Bearing capacity of strip footings above void, Journal of Geotechnical Engineering, 1983, 109(1), 1-14. Downloaded from ascelibrary.org by Southern Illinois University, Carbondale on 06/06/15.

[4] M. C. Wang, Yoo C. S. and Hsieh C. W., Effect of Void on Footing Behavior under Eccentric and Inclined Loads, Foundation Eng. Journal, ASCE, 1991, 1226-1239.

[5] Badie, A. and M. C. Wang, Stability of spread footings above void in clay, Journal of Geotechnical Engineering, 1984, 110(11), 1591-1605.

[6] Joon K. L., Sangseom J., Junyoung K., Undrained stability of Surface Strip Footings above Voids, Science Direct Journal of Computers and Geotechnics, Vol. 62, 2014, pp. 128-135. http: //dx.doi.org/10.1016/j .compgeo.2014.07.00 9.

[7] Makoto K., Masatoshi O., Osamu K. and Fang-le P., Yielding Pressure of Spread Footing above Multiple Voids, ASCE, Journal of Geotechnical and Geoenvironmental Engineering, Vol. 133, 2007, No. 12, pp.1522-1531.

[8] Rodriguez-Roa F., Ground subsidence due to a shallow tunnel in dense sandy gravel, J
Geotech Geoenviron Eng ASCE, 2002, 128(5):426-434.

[9] Mohamed M.A. H., Stability of strip footing on sand bed with circular void, Journal of Engineering Sciences, Assiut University, Faculty of Engineering, January 2014, Vol. 42, No. 1.

[10] Al-Neami, M. and Wasmi, M., Influence of cyclic loading on performance of steel piles in sandy soil, Paper presented at the MATEC Web of Conferences, 2018, 162.

[11] Akdag, C. T. and Özden, G., Nonlinear behavior of reinforced concrete (RC) and steel fiber added RC (WS-SFRC) model piles in medium dense sand, Journal of Construction and Building Materials, 2013, 48, 464-472.

[12] Ashraf N. and Ahmed N., Pullout capacity of batter pile in sand, Journal of Advanced Research, 2013, 147-154.

[13] Dharmatti, V. and Rakaraddi, G., An experimental study on vertically loaded driven and cast-in-situ piles, Journal of Mechanical and Civil Engineering (JMCE), 2014, 11(2), 43-48.

[14] Mohamed A. S., Ashraf K. N., Waseim. R. A. and Ahmed F. S., Model study of single pile with wings under uplift loads, Journal of Applied Ocean Research, 2020,100, 102187. https://doi.org/10.1016/j.apor.2020.102187.

[15] Calogero V., Maurizio Z. and Sandro R. M., The bearing capacity of footings on sand with a weak layer, Geotechnical Research, Volume 4 Issue GR1, 2017, http://dx.doi.org/10.1680/jgere.16.00020.

[16] M. Salih K. and Mustafa L., Experimental and Numerical Studies of Strip Footings on Geogrid-Reinforced Sand Slope, Research Article - Civil Engineering, Arab J Sci Eng, 2014, 39:1607-1619. DOI 10.1007/s13369013-0795-7.

[17] Mostafa A. El S., Waseim A. and Engy K., Bearing capacity of a strip footing adjacent to a sand slope with soft pocket, International Conference on Advances in Structural and Geotechnical Engineering, 29-31 March 2021, Hurghada-Egypt.

[18] Vesic AS., Analysis of ultimate loads of shallow foundations, J Soil Mech Foundations Division, ASCE. (3):,1973, 661-688.

[19] S.V. Anil K. and K. Ilamparuthi, Response of footing on sand slopes”, IGC 2009, Guntur, INDIA, 622-626.

[20] Arash A. L. and Mahmoud G., Behavior of Shallow Strip Footing on Twin Voids, Geotechnical and Geological Engineering, February 2016, DOI: 10.1007/s10706-0169989-6. 
[21] Tapan K. N., Koushik H. and Debarghya C., Experimental Investigation on the Behaviour of Geogrid-Reinforced Soil Slope under Strip Loading, Indian Geotechnical Conference 2017 GeoNEst14-16 December, IIT Guwahati, India.
Copyright (C) Int. J. of GEOMATE All rights reserved, including making copies unless permission is obtained from the copyright proprietors. 